\title{
Radical Re-tellings of Hir: Gender and the Politics of Voice in Postcolonial Punjabi Poetry
}

\section{Sara Kazmi}

\section{OpenEdition}

\section{Journals}

Electronic version

URL: http://journals.openedition.org/samaj/5294

DOI: $10.4000 /$ samaj.5294

ISSN: 1960-6060

\section{Publisher}

Association pour la recherche sur l'Asie du Sud (ARAS)

\section{Electronic reference}

Sara Kazmi, « Radical Re-tellings of Hir: Gender and the Politics of Voice in Postcolonial Punjabi Poetry », South Asia Multidisciplinary Academic Journal [Online], Free-Standing Articles, Online since 20 May 2019, connection on 29 May 2019. URL : http://journals.openedition.org/samaj/5294 ; DOI : 10.4000/ samaj.5294

This text was automatically generated on 29 May 2019.

\section{cc)}

This work is licensed under a Creative Commons Attribution-NonCommercial-NoDerivatives 4.0 International License. 


\title{
Radical Re-tellings of Hir: Gender and the Politics of Voice in Postcolonial Punjabi Poetry
}

\author{
Sara Kazmi
}

\section{EDITOR'S NOTE}

This paper received the Student Research Award from the European Association for South Asian Studies at the 2018 European Conference on South Asian Studies held in Paris.

"Ni Hiray,

Ranjhan tere da naa(n)

Ki hoya je maulvi lainda

Lai laindi amree te babul vi lainda

Te bhanvai(n) lainda sabh gara(n)

Par ikje Hiray $\mathrm{tu}(\mathrm{n})$ na laindi

Te aj kon lainda ohda naa(n)

Sadian picho(n) vi aj kurian

Apne apne sajan da

Rakh daindia(n) ne Ranjha naa(n)

Ni Hiray,

Ranjhan tere da naa(n)"1

[O Hir,

The name of your Ranjhan, Who cares if the maulvi took it, Mother can take it, father does too, Brothers take it, and their wives too,

So what if the whole village took it,

But if, O Hir, you hadn't taken it Who would have taken his name today? 
Even centuries later, girls today

Name their lovers Ranjha.

O Hir,

The name of your Ranjhan.] (Pritam N.d.:2)

1 This poem from Amrita Pritam's Navin Rutt (The new season) captures the tender, sensuous lyricism that characterized much of her "love poetry," a form that dominates her highly acclaimed 1955 anthology Sunehade (Messages). In the poem cited above, Amrita Pritam (1919-2005) references the narrative of Hir and Ranjha, a story that has circulated in oral, textual and performative form in Punjab since the sixteenth century. The playful tenor of the poem is established by the repetition of "na(n)" (name) and " lainda/laindi" (taking/takes [the name of Ranjha]), a soothing mix of vowels and nasal sounds that mimics the cadences of a folksong. The quality of banter is accentuated by invoking the structure of the popular riddle in Punjab (Syed 1968:85), which is often designed around lists combining a series of negations. The poem lists the characters that “take" Ranjha's name: mother and father (Hir's parents), maulvi (a village cleric who Ranjha has had an altercation with), and brothers and their wives (Ranjha's brothers and their wives who cheat him out of his inheritance and push him out). The tone of lively teasing is augmented by Pritam's use of pet names for Hir ("Hiray") and Ranjha ("Ranjhan"), creating a sense of intimacy and endearment that culminates in, and in a way affirms the enduring influence of the Hir narrative in popular memory today-"Even centuries later, girls today/Name their lovers Ranjha."

Mir (2005) argues that colonial-era retellings of Hir reveal a shared Punjabi ethos rooted in a sentiment of belonging and cross-communal notions of piety. Pritam's poem signals how the qissa $a^{2}$ continues to exercise the imagination of lovers and poets even in the postcolonial period, and also sheds light on the history of contestation that has surrounded the Hir tale. A subversive, feminist reading of the Hir-Ranjha romance is embedded in Pritam's poem reproduced above, "O Ranjha, your name." While the title and the first half of the poem are addressed to Ranjha, the second half shifts the focus to Hir. Her re-naming of Dhido as Ranjha transforms him from a masculine subject into a lover who forsakes everything, including the identity he received from his patriarchal home. Hir has the power to name. It is through this power that she brings Ranjha into existence and gives him a place in history. When women name men Ranjha centuries later, they embody her constitutive power.

In her famous poem, "Aj Akhan Waris Shah $\mathrm{Nu}$ " [Today I call on Waris Shah], Pritam continues this practice: she reconstitutes Waris Shah to implicate regional and nationalist patriarchies in the gendered violence of the Partition of Punjab in 1947. Thirty years later, across the border in Pakistan another feminist poet, Nasreen Anjum Bhatti (19432016) deploys the same technique. Bhatti builds on Hir and Pritam's interpretive interventions to "turn another page in the book of love." 3 She creatively worked the tale of Hir Waris Shah into her verses to address the authoritarian context of a repressive military regime whose cultural foundations rested on the control of women's bodies. The question for Pritam and Bhatti was: How can we construct a feminist poetics of the vernacular that remains equally critical of nationalist, regional and communal patriarchies? How can we craft a poetic language rooted in the land, that does not reify the distinction between region and nation, vernacular and metropolitan, tradition and modernity? 
This paper explores answers to these questions by analyzing the literary after-lives of the Hir folktale in postcolonial Punjab. Drawing on an analysis of the Hir-Qazi dialogue in Hir Waris Shah, I will argue that Hir texts from the Punjabi tradition furnish a de-centering of male authorship, a template for reinterpreting tradition and a dialogic tension that facilitates Pritam and Bhatti's poetic intervention to address points of historical, political and cultural conjuncture in Punjab through a gendered lens. Pritam invokes Hir Waris Shah at the cusp of independence to fashion a feminist take on the debate on national culture triggered by decolonization and Partition in India and Pakistan. Bhatti, for her part, builds on her insights to construct a vernacular feminist historiography that challenged the Islamist-patriarchal narrative of the military dictatorship in postcolonial Pakistan. Both poets accomplish this by unique yet related literary techniques: Pritam develops and inverts Waris Shah's symbolism surrounding poison from the folk classic, while Bhatti adopts Hir's voice to undertake a feminist revision of the myth of Bhaag Bhari (Waris Shah's lover). Together, their poems offer a historiographical and literary reconstruction of cultural identity to locate women as active subjects and narrators of history.

In a broader sense, this exploration will also attempt to reconfigure the relationship between regional writing and literary radicalism in postcolonial contexts. As Gopal (2005) argues, the hackneyed distinction between the "politicals" and the "men of taste" (p. 3) flattens the complexity of texts that combine a universalist pursuit of social transformation with intimate, particular insights into experience and affect. Punjabi writers such as Pritam and Bhatti faced a double bind-in that poetry in the regional languages is excluded from the purview of "national high culture" a space that a language like Urdu or Hindi can occupy. Writing in Punjabi is ignored in debates on Left-wing literary production in North India, relegated to "regional confines" (Kaviraj 2005) and seen as "subaltern discourse" (Kaviraj 2005) that is necessarily local in its political and cultural outlook. This relegation of regional vernaculars and their literatures, and their alienation from important public debates around gender, national reconstruction and political transformation is rooted in the hierarchy of languages instituted by colonial knowledge in South Asia, which designated Urdu, Hindi and English as "languages of command," while Punjabi and other regional languages were consigned to "vulgar tongues" (Cohn 1996), or "rural patois" (Mir 2010) unsuitable for government and cultural production. For Bhatti and Pritam, who were shrewdly aware of this linguistic stratification of Indian culture and society, writing in Punjabi and paying homage to Hir stemmed from an effective attachment to their mother tongue. It also represented a political choice that responded to the imperialist marginalization of regional literary culture and to chauvinist nationalist critiques of South Asian feminism that viewed the woman question as a western import imposed by colonial modernity. In their reflective turn to Hir, our poets not only "think with modernity, against modernity" (Lazarus 1999:6), but also think "with tradition, against tradition."

\section{The voice of Hir as a genre of critique}

6 The character of Hir as portrayed in Hir Waris Shah inaugurates a literary mode of disputation to challenge existing moral and spiritual authority. This tussle for female voice, a thematic developed by Pritam and Bhatti, is embedded in the originary text itself. The story of Hir has circulated in the Punjabi oral and poetic tradition for at least the past 
four hundred years, in the form of kafis, dohas, qissas, folksongs and raas (theatre). The first extant text can be traced to Damodar Das (c. 1605), but references to the narrative predate the popularization of the Punjabi qissa form, as the story surfaces in the oeuvres of Shah Hussain (c. 1530s-1600) and Bhai Gurdas Bhalla (c. 1550s-1635) as well ${ }^{4}$ (Mir 2010:7). However, it is Waris Shah's eighteenth century qissa that has acquired a canonical status for literary critics, and remains the most popular choice for oral performance, usually rendered in a signature melody unique to Hir Waris Shah. Dhido (Ranjha), after a dispute with his brothers over their father's land, leaves his hometown Takht Hazara with nothing but his flute in hand. He embarks on a journey that takes him to Jhang, where he meets Hir and they fall in love. On her suggestion, he joins her father's household as a cowherd, but the love affair is eventually discovered, at which point Hir's parents marry her off to the wealthy Khera clan. Ranjha, disguised as a jogi, ${ }^{5}$ follows Hir to her in-laws' house in Rangpur, where the two decide to elope. The runaway lovers are eventually tricked by Hir's family, with a false promise of marriage. While Ranjha returns to Takht Hazara for the ceremonial preparations, Hir is poisoned. He dies of shock upon hearing the news (Syed 1968:44).

7 Hir's hermeneutical subversion comes across forcefully in her exchange with the Qazi. This can be considered a defining episode in the Hir narrative, featured in all textual and performative tellings. The episode occupies a pivotal moment in the story-the love affair between Hir and Ranjha has been discovered and her parents have vowed to marry her off to Saida, a wealthy scion of the Khera clan. It is here that Hir furnishes the Punjabi literary formation with an ur-text of feminist critique. While Deol (2002) views Waris' heroine as a "markedly subdued Hir who speaks from within the bounds of social and literary convention" (p.145), I will argue that Hir's character becomes integral to the text's "ironical interrogation" of the relation between faith and rite in religion" (Matringe 1995:203). Her reinterpretation of tradition ultimately subverts the Qazi's discourse, and she forces her way into domains of discourse traditionally denied to women.

The Qazi announces his arrival with a strong, imperious pronouncement highlighting his claim over orthodox religion, "Qazi mehkmai vich irshad kita, man Shar'a da hukm je jivna ai" [Qazi declared in the court, obey the orders of the Shariah if you want to live] (Stanza 205). ${ }^{6}$ By referring to his "declaration" in the "court," the Qazi also impresses upon Hir his access to the male public sphere. He then presents tenets of this patriarchal domain to Hir in the form of religious commandments: "Bad maut de nal iman Hiray, dakhil vich bahisht de theevna ai/... Chadar nal hya de satr kijay, kah darz haram da sivna ai." [After death, we will only enter heaven if we have faith/... Cover your head, have some shame, only so can you stitch up (your) transgressions.] (Stanza 205) Hir's first blow in this hermeneutical contest works by turning the Qazi's religious discourse around the Day of Judgment upside down:

Hir akhdi, jivna bhala soi, jehra hovai bhi nal iman, mian,

Sabh jag fani, hiko rab baqi, hukm kita hai rab rahman, mian,

'Qul shi'i khalqnazu ji'in,' hukm aya hai vich Quran, mian,

Mere ishq nu(n) janda dhol bashik, loh qalm, zamin asman, mian.

[Hir says, life is only worth living, if one has faith here and now, mister,

This world is illusory, only God is real, that is His merciful command, mister,

"We have created everything in pairs," it has been mandated in the Quran, mister,

My love is known to the Bashik serpent, the Pen of Destiny, heaven and sky, mister.] (Stanza 206) 
While the Qazi mandates that "faith" is essential to enter heaven after death, Hir counters this injunction with a conviction that faith is necessary, here and now, to do justice to life on earth. In a single line, Hir shifts the grounds of the discussion from the abstract, lofty heights the Qazi has adopted to the messy materiality of human relationships. She also opens the floor to her re-interpretation of "faith" as love, her unwavering commitment to Ranjha against all familial and social odds. She hints at this through the Quranic verse she cites in the original Arabic, "We have created everything in pairs" (51:49).

9 As the dialogue progresses, Hir claims that she was given Ranjha through her pleas at the "dargah," the word commonly used to denote a shrine across all three major religions of Punjab, Islam, Sikhism and Hinduism. Hir's interpretive maneuver combines, and thus reworks, both scriptural Islam and popular spirituality, as she intersperses her utterances with snatches of Quranic Arabic and references to the "dargah" and the "qutb." Both these institutions are associated with the popular religious practices of Sufism, a domain abhorred by the likes of the orthodox, Shariah-wielding Qazi. In fact, in the last line of the stanza quoted above, Hir's instrumentalization of tradition widens to include ancient Sanskritic mythology through the invocation of the Baashik serpent or Vasuki as it is called in Sanskrit. The serpent was used as a rope to churn the oceans into existence before the beginning of life on earth. To the primordiality and creational significance of this great snake, Hir adds the testimony of the elements, sky and earth, and of "loh qalam " which translates directly as "pen and tablet," but also points us towards the "Pen of Destiny" referred to in Islamic tradition, the hidden or indelible documentation of all of humankind's deeds since eternity. Interestingly, while the Qazi looks ahead to life after death and the day of judgment to buttress his position, Hir takes us back in time, to traditions of origin (the Baashik snake) and to the timeless, constant existence of nature (earth and sky). At the same time, while the invocation of "loh qalam" strengthens her claim to antiquity and tradition, it also highlights the importance of Hir's human agency, signified by the literal meaning of "pen and tablet." The pen is after all a tool of the thinking, acting human, one who can write her own destiny.

In this dialogue spanning fourteen stanzas, Hir's rhetorical prowess continues to deliver masterstrokes one after the other. The exchange becomes more heated, and threats from the Qazi continue to pour forth, yet Hir refuses to back down, ultimately leading him to conclude:

Qazi akhya, ai je ror pakka, Hir jhagreyan nal na hardi ae,

Lao parho nikah, munh banh is da, qissa koi fasad guzardi ae,

Chad masjidan, dairian vich vardi, chad bakrian surian chardi ae,

Waris Shah, madhani ae Hir jatti, ishq dahi(n) da ghiyo natardi ae

[Says Qazi, she is an unwielding stone, Hir cannot be defeated through arguments

Tie her up, gag her mouth, and marry her off, she is making trouble with her stories

Shunning mosques, she sits in councils, ${ }^{8}$ she grazes hogs instead of sheep

Waris Shah, Hir churns love's yogurt to refine ghee.] (Stanza 218)

The Qazi loses the war of words, but prevails through recourse to sheer force. His admission that Hir "cannot be defeated through arguments" is coupled with a deep anxiety regarding her challenge to the religious and patriarchal tradition he represents. This is manifested by his anger at her brazen intrusion into the exclusively male sphere of "councils," an act he likens to domesticating pigs: a despicable, deviant practice because these animals are considered abhorrent to Muslims, and their consumption is forbidden in Islam. Waris Shah, as diegetic author, steps in here to have the last word: 
"Waris Shah, Hir churns love's yogurt to refine ghee." Yet that is not how ghee is made: milk is churned to obtain butter, which is then boiled slowly to yield ghee. In fact, it is impossible to obtain ghee from yogurt, because once the milk curdles, it cannot produce butter. Hir has accomplished the impossible, and this impossibility hints at a dialogic tension between author and character-Hir's rhetorical power looms large enough to threaten and overwhelm her creator, the poet himself. Encapsulated in Waris Shah's own concluding remark, this tension is also relayed to us through the Qazi, who becomes a mouthpiece for this authorial anxiety: "Khera haq halal qabul kar tu(n), Waris Shah ban baithi ai dhitiay ni" [Accept the Khera (as your husband) by law and right, you have become Waris Shah himself, o stubborn woman"] (my emphasis) (Stanza 207). Herein lies Hir's highest transgression-a female character indebted to the eloquence and wit bestowed by the qissa poet inevitably yanks the reins of narrative away from the male author and appropriates his voice as her own. This looming and overwhelming quality of Hir's voice becomes a topos in popular Punjabi poetry, a dialogic play that is used to censure the nexus between orthodox religion and social control, but also imposes limits on the authorial ego of the male poet.

11 Despite being a rich terrain for contestation, most readings of Hir Waris Shah and the Punjabi kafi $i^{9}$ remain wedded to abstract frameworks of "Sufism" or mysticism. ${ }^{10}$ As Ahmad (1992) argues, literary and religious canonicity emerged at the same time and have overlapped in Indian history, a development that has emphasized the "sublimity" of texts such as Hir Waris Shah to the point that it can no longer be "read in relation to the secular conditions of its production (n)or as an ideological text whose main task is to offer an imaginary resolution in the secular, familial and material domains" (Ahmad 1992:260-61). This produces an exaggerated bifurcation between precolonial literary tradition and contemporary writing, a distinction challenged by Pritam's reflexive approach to Hir texts in "Today I call on Waris Shah." In his essay titled, "Where mirrors are windows," A.K. Ramanujan (1989) discusses the role of such a "reflexive intertextuality" in furnishing Indian literature with a "common yet creative language of dissent." (p. 208) Pointing to the indictment of the Brahminical tradition in Bhakti literature, he unites the two in a shared repertoire in which texts mimic, reflect and critique each other. For Ramanujan (1989), "modernity disrupted [the] whole tradition of reflexivity with new notions of originality and autonomy of single works" (p. 190). However, the relationship that Pritam establishes between her poem and Waris Shah's Hir militates against this reading of literary modernity. Pritam's poem connects with Waris Shah's Hir as Ramanujan's "akam-puram" texts do, embodying all three facets of "reflexivity"-it responds to Waris Shah's text by directly addressing him in its title and de-centering his authorial control, it reflects on his Hir by contextualizing its serpent/ venom imagery in the contemporary era, and lastly, it is "self-reflexive" in Pritam's exploration of a postcolonial feminist poetics of the regional vernacular.

\section{Reworking Hir: the "poison" of patriarchal nationalism in Pritam's "Today I call on Waris Shah"}

12 Already a distinguished poet in 1947, at the young age of twenty-eight Amrita Pritam found herself relocating to East Punjab as riots broke out in the wake of an impending partition of the sub-continent. Having made the journey on which countless others perished, the violence and destruction wrought by Partition would spur her to write her 
most well-loved and oft-quoted poem: "Today I call on Waris Shah." Celebrated across the border in both Punjabs, for many the poem elicits the pangs of nostalgia and loss of being uprooted from their homelands. However, in my reading, Pritam's poem does not merely bemoan the violence of Partition: it provides a feminist critique of regional and national patriarchies. This is accomplished by an appropriation of Waris Shah's authorial privilege -in the tradition of Hir's voice-to present a feminist reconstruction of identity that participated in a debate on national culture on both sides of the newly-created border.

Pritam's initiation into the Indian literary sphere, and her interest in the themes of national reconstruction were shaped heavily by the Progressive Writers' Movement (PWA). The PWA constituted "a hugely influential radical cultural movement that spanned several regions and languages across India... this movement was closely linked to debates over decolonization and the nature of the postcolonial nation-state that was to come into being" (Gopal 2005:1). This influence was seen most directly in Pritam's 1944 anthology, Lok Peed (People's Anguish), which criticized the colonial economy, particularly in light of the Bengal famine of 1943. The PWA's anti-colonial project resonated deeply with the young Pritam, as did the "particularly instructive" and "constitutive" (Gopal 2005:5) role that gender played in the literature produced by her progressive contemporaries. ${ }^{11}$ Yet writing in the regional vernaculars, such as Punjabi, remained a marginal practice in the PWA. Despite the organization's regional branches, it garnered most influence in North India, where Urdu dominated as a language of culture. Most leading members of the PWA, even those who were native Punjabi speakers, chose to write in Urdu. This choice was tied to their class (most urban, middle-class Punjabis were educated in Urdu), as well as a political commitment to forging a unified national culture for India or Pakistan. As Asdar Ali (2011) argues, this also indicated a shared consensus on Urdu among North Indian ashraf elites across the ideological spectrum (p. 501). Pritam however, wrote extensively in her mother tongue, despite grappling with the issue of limited readership for regional writing:

My initial reaction at an early stage of my writing career was to stop writing in the language if I couldn't reach through it to my people. I said to myself: "No more Punjabi for me." But as I thought calmly about it, the writer in me decided, whatever the consequences, I couldn't write in any other but my mother tongue. That relates me to my soil, my milieu. And I gave myself wholly to Punjabi. (Jha and Pritam 1982:194)

Her choice to write in Punjabi thus grafted the question of vernacular tradition and regional culture onto the intersecting themes of women's emancipation, political responsibility, religion, caste, class and citizenship that framed the progressive debate on national culture in the years leading up to, and following, independence.

Pritam's poem works by mimicking the structure and form of Hir Waris Shah, exploiting the narrative technique of oral tradition by dwelling on chosen episodes without regard for transitions (Matringe 1995:206). Like the eighteenth century text, "Today I call on Waris Shah" powerfully conjures a sense of place by drawing on images of the Punjabi landscape and rural life: the fields, the river Chenab, the earth, the spinning wheels and the Pipal tree. Waris Shah's Hir begins in much the same way, with detailed descriptions of Takht Hazara, the village where Ranjha lived with his brothers and father. Hazara is described as "paradise on earth," a bountiful hamlet whose inhabitants, ostensibly seem to engage in little more than merriment. ${ }^{12}$ This exuberant description is followed by Waris Shah's first dose of ironic contrast (Syed 1978:45), as he follows his hyperbolic description of Takht Hazara with a stanza exposing the corrosive jealousy of Ranjha's 
brothers towards him. The brothers are compared to venomous snakes that strike Ranjha's heart mercilessly, completing the biblical imagery by placing a serpent in paradise (p. 47). Pritam similarly evokes the geography of the land, complementing her description of the landscape with tropes from the folk tradition such as Ranjha's flute and the girls' trinjann. ${ }^{13}$ The juxtaposition of the physical landscape with regional cultural symbols conjures a counter cartography of Punjab-constituted neither by the imperatives of the colonial state, nor by the aspirations of the mainstream nationalist movement. Her verse constructs a cultural geography of the region, its contours sketched by the qissa of Hir. Yet Pritam's grounding in a precolonial literary tradition does not lead to a romanticized view of region and community as the primordial, utopic martyrs of colonial oppression and nationalist modernity. As the poem progresses, Pritam's deployment of the Hir narrative deepens her analysis of the nexus between Punjabi patriarchy and Indian/Pakistani nationalism. Just as in Waris Shah's Hir, the serpent and its poison become central to establishing this linkage.

Hir Waris Shah makes repeated use of the serpent motif that reappears in the description of Kaido, Hir's uncle and nefarious village outcast, who exposes the lovers to the village council and plays an instrumental role in marrying Hir off forcefully. The serpent, used exclusively to refer to male characters, appears first in Takht Hazara to signify the corruption wrought in familial relations by greed, and then to represent the need to regulate women's bodies and sexuality. It becomes a symbol of patriarchal control and toxic masculinity, lurking menacingly in the domestic and the public sphere, in Ranjha's home and in Hir's village. However, in the aftermath of Hir's altercation with the Qazi, once she is married and forced into a palanquin, the serpent and poison motif undergoes a subtle transformation. Waris Shah follows a series of stanzas detailing the ostentatious contents of Hir's dowry, with one in which the snake and venom reappear in a new form:

Sak mareya(n) de kho lain dadhai, anpujde o na boldai ni

Nahi chalda vas lachar ho ke, moai sap vangu(n) vis gholdai ni...

...Gun mareya(n) de sabhai rehn vichai, maray mareya(n) de dukh pholdai ni...

Waris Shah lutainde ghari(n) maray, maray khauf de munh o na kholdai ni.

[The mighty snatch the relations of the weak, the wretched, they cannot even speak

Rendered helpless, hapless, all they do is dissolve poison like a dying snake...

...The strength of the weak remains repressed, their grief directed towards one another...

...Waris Shah, the weak are robbed in their own homes, they cannot even speak out of fear.] (my emphasis; Stanza 190)

This stanza, with a sub-heading titled, "The cry of Ranjha," ${ }^{14}$ highlights his plight as he watches his beloved borne off to her in-laws' village in Rangpur, a captive of her own wedding procession. Thus, in an immediate sense, the victims here are Hir and Ranjha, yet Waris prefers the generic category of "the weak" or "the wretched" to paint his picture of suffering. The line "moai sap vangu(n) vis ghoaldai ni," which I have translated as "dissolving poison" refers to an idiom in Punjabi-the act of "dissolving" or "stirring" poison is used colloquially to refer to repressed anger, conveyed by the image of absorbing and concentrating poison, internalizing rather than purging it. As the entire village, including its low-caste, low-class denizens, participate in Hir's wedding, the spread of this patriarchal venom is captured in the line: "they dissolve poison like a dying snake." Patriarchal authority stands internalized by society as a whole, it is no longer embodied solely by Ranjha's brothers and Kaido. The wretched and poor become both sufferers and perpetrators-as the pomp and splendor of Hir's dowry comes to represent economic exploitation, a regime under which "they are robbed in their own homes." The 
victims are drawn from the same ranks that are mobilized to maintain the feudal, patriarchal status quo.

Pritam reworks this play on "dissolving poison" to analyze the carnage and social devastation wreaked during Partition. In her poem, this idea of venom or poison is generalized into ideology, which in this case, takes the form of a masculine nationalism informed by communal consciousness. Thus, "I call on Waris Shah" underlines the destructive and inter-related role of colonial complicity, nationalist ideology, regional patriarchy and religious identity in creating a situation in which ordinary people turned to killing their own neighbors, "their grief directed towards one another" (Stanza 190). She develops the serpent metaphor to give us the powerful image of venom being dissolved into the land itself, spreading through the life-giving flow of the river that subsequently "drenched the earth" itself:

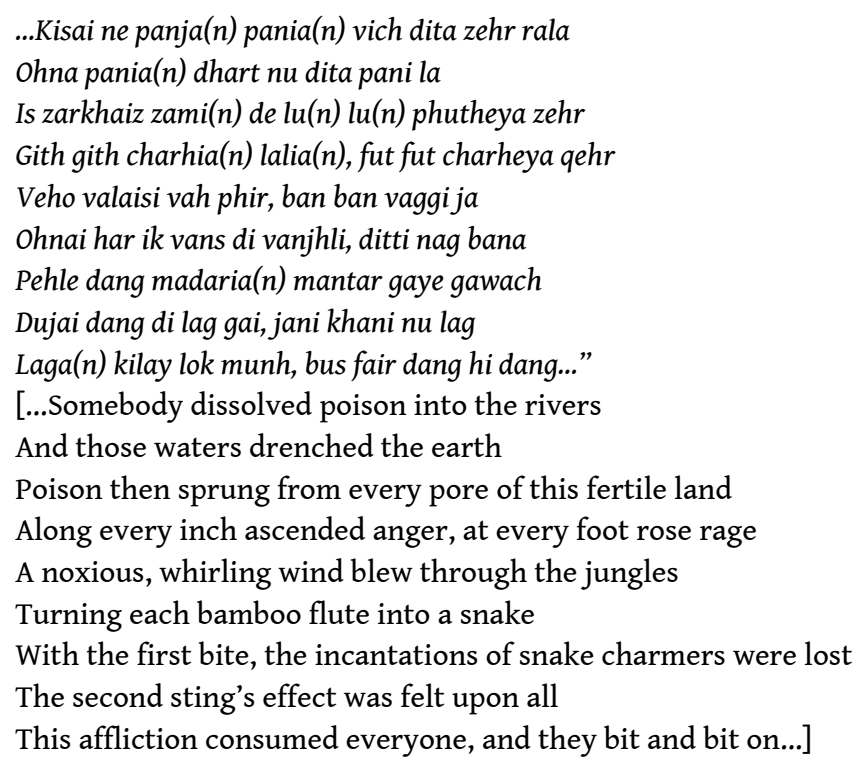

Similar to the "stirred poison" in Waris Shah's verses, the venom is no longer an external agent acting on the body of Hir, who is eventually, significantly, poisoned in the story-it is toxic matter that has seeped into the very substance of the body politic of Punjab. Polluting the air itself, in the form of a "noxious, whirling wind," its destructive contents have been breathed in and ingested by the entire population, turning them all into snakes ("they bit and bit on") (my emphasis) that attack each other. Pritam also hints at colonial complicity in nurturing this beast through policies that communalized identity in Punjab, suggested by the othering tone of "somebody dissolved poison into the rivers" (my emphasis). In many ways, Pritam exaggerates and extends Waris's symbolism to mark the enormity of historical rupture created by Partition in Punjab, as the bamboo flute, the pristine symbol of Ranjha, also undergoes this heinous transformation. As Punjab is carved up, the venomous serpent of patriarchal ideology grows into a ferocious Hydra, it's many-headed form signifying the convergence of the "multiple patriarchies [national, colonial and communal] at work in women's lives." (Menon and Bhasin 1993:WS3)

As Menon and Bhasin point out, "the location of women at the intersection of these forces, rather than at their periphery, cast(s) an entirely new light on the apparent fixity of defining features of identity like community, religion, nationality." (p. WS2) It is this intersectional position of gender that informs Pritam's feminist revision of vernacular roots. Partition may have been "over," and the transition from colony to nation completed in a literal sense. Yet the process of cultural and social reconstruction has just 
begun, a challenge to which Pritam responds through Hir's mode of contestation, to inscribe women's agency within the Punjabi literary tradition. The opening and closing lines of Pritam's poem almost work like a kafi's refrain, drawing on the dialogic tension created by the insertion of the poet into the "takhallus" or poetic signature. By addressing Waris Shah, Pritam reverses the "vocal masquerade" (Petievich 2008) of Punjabi poetry in which men speak as women to men, to create a reflexive text in which women speak for themselves, addressing men:

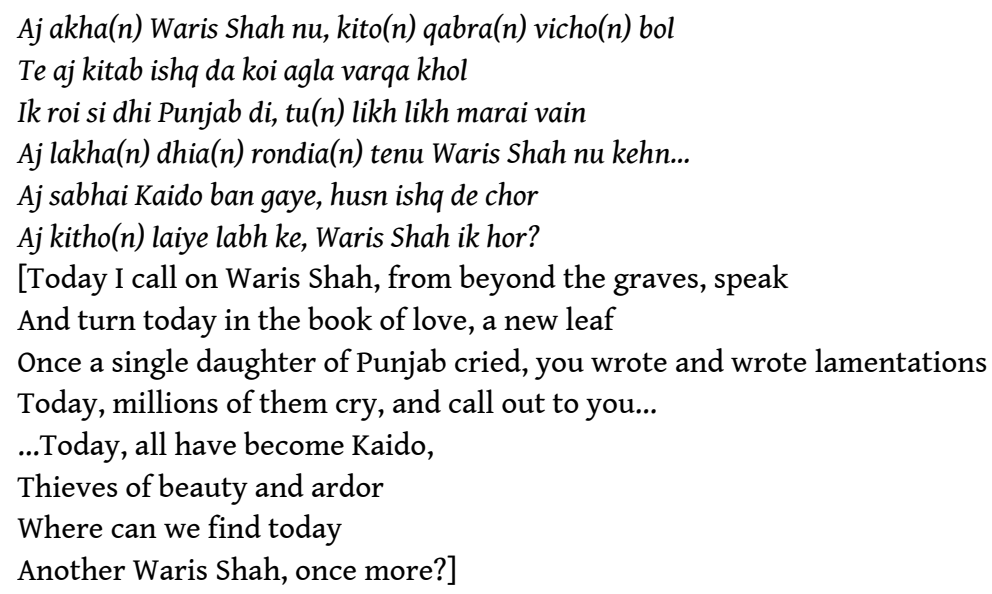

The hint of irony in the last two lines cannot be missed. Where can we find another Waris Shah to speak the unspeakable truths of Partition? Where can we find a man who can give voice to the ordeals of the voiceless women? Where can we find a man who can fashion an emancipatory cultural identity in a society that has made clear that the burden of nation formation will fall so heavily, so literally, on the body of the woman? "Today I call on Waris Shah" is itself the answer to this question. Pritam appropriates the role of Waris Shah, a woman taking ownership of the centuries old tradition of the Hir narrative, which has largely been the domain of male poets. She establishes her feminist revisionist intent from the very outset, as the poem's opening invocation of Waris Shah can easily be read in the tone of a sharp rebuke-speak Waris Shah, you are dead and long gone, but arise from your grave, for you must! The sheer scale of violence in the Partition, the uncountable rapes, abductions and murders of women calls for this macabre resurrection of the poet who penned the most beloved ballad of the land. Yet this resurrection is not merely an act of nostalgia stemming from a romantic sense of cultural loss-it is also Pritam's attempt to prize away male authorial privilege to fashion a feminist reworking of cultural identity and nationalist critique that becomes imperative to the nascent process of nation-building. Much like Hir's hermeneutical challenge to the Qazi at the height of crisis in the narrative, a woman must rise to the task of re-interpreting tradition and appropriating the intellectual tools of the male at a time of great upheaval following decolonization.

In a sense, the fractures inaugurated by Partition revealed themselves at a microcosmic level in responses to Pritam's poem among literary circles in Pakistan and India. In her autobiography, she suggests that the poem invited some controversy, writing how the Sikhs deemed her guilty for not addressing her invocation to Guru Nanak (Jha and Pritam 1994:32), while some Pakistani intellectuals viewed it as a scourge on the moral legitimacy of the Muslim nation, criticizing her for not having accepted "the reality of the cartographical fact of Pakistan" (Jha and Pritam 1994:24). The communists, on the other hand, were disappointed that Pritam chose not to call upon Lenin (Jha and Pritam 
1994:32)! While Pritam may have been caricaturing what she refers to as "communist" critiques of her poem, these responses emblematize the widening rift in postcolonial Punjab between models of progressive cultural politics. In a political context that became increasingly defined by linguistic nationalism, leading to a further division of Indian East Punjab in 1966, and rising demands for a Siraiki province in south Punjab in Pakistan, "Today I call on Waris Shah" initiates a crucial conversation between the universalist visions of emancipation provided by Left-wing perspectives with particular, regional histories and vernacular identities. Pritam's poem addresses both progressive writing and the Punjabi literary sphere, in an attempt to synthesize the concerns of both vis-à-vis the relationship between region and nation, local and universal, gender and cultural identity. For Mir (2010), "Today I call on Waris Shah," reads as an "elegiac" poem that mourns the demise of "the ethos of the Punjabi literary formation" (p. 183), that seemed "to wane at the cusp of independence and diminish further during the postcolonial period" (p. 183). However, when read as a postcolonial reworking of pre-colonial Hir texts, we find that Pritam's poem re-invigorates the trope of argumentation and interpretive contest in Punjabi literature to construct a dynamic poetic engagement with regional roots. Pritam lays the ground for Bhatti, who builds on her framework to confront the effacing of women in Pakistan's public sphere with a feminist historiography rooted in the vernacular.

\section{Rewriting Hir under a postcolonial authoritarian regime: Bhatti's "Blue cloth dyed blue"}

Nasreen Anjum Bhatti's (b. 1943) first book of poetry, Nil karaiyan nilkan ${ }^{15}$ (Blue cloth dyed blue) was published in 1979, mere months after a military coup that led to the hanging of the country's elected Prime Minister, Zulfiqar Ali Bhutto. With General Zia ul Haq as the Chief Martial Law Administrator, this regime would then proceed to push Pakistan into the Afghan jihad, Islamized law and government, and attempt a fundamental transformation of society along Sunni orthodox lines. Control over women's bodies and their participation in the public sphere became the cornerstone of General Zia-ul-Haq's draconian project of cultural reconstruction, forged through a perverse mix of regional patriarchy and "anti-female tenets" in Islam (Rouse 1986:30). In this context, a radical women's movement emerged whose clarion call identified the patriarchal quadrangle of "men, money, mullahs and military" as the enemy of progressive, democratic forces in Pakistan. Bhatti was swept into politics by the wave of Left-wing activism that accompanied the rise of Bhutto's Pakistan People's Party in this period. ${ }^{16}$ She was also an active member of various progressive women's groups that participated in the critical debates focusing on the intersection of feminism and democratic restoration. Framed by these concerns, Blue cloth dyed blue also contained one of her most well-known poems, " Bhutto di vaar" (The ballad of Bhutto), a eulogy to the progressive promise that Bhutto held for many, relayed in the idiom of the var ${ }^{17}$ genre that celebrated quasi-historical heroes. This reworking of a regional genre from Punjab to write an anthem of resistance that emblematized the struggle between democratic forces and military dictatorship in Pakistan, alerts us to her interpretive interest in the literary tradition, whose feminist revisionism is laid out in her title poem, "Nil karaiyan nilkan." 


\section{Bhaag Bhari: recovering "missing" women in Punjabi poetics}

In "Nil karaiyan nilkan," Bhatti vacillates with such increasing rapidity between Hir's persona and her own interjections that a disembodied, supra-human narrator emerges. This poetic voice is like a female force reminiscent of the goddess Kali or simply "Kaal" as she is referred to in the folk ballads of Punjab. ${ }^{18}$ Simultaneously, the "I" also drives home the individual, inserting the poet into the precolonial cultural world, into the very center of the literary tradition. Time begins to collapse as Hir and Bhatti meet across the centuries, and the probing question to Waris Shah in Pritam's poem is transformed into a full-blown interrogation of the male lineage of the Punjabi literary tradition. In this imaginative confrontation by Bhatti, we are introduced to a "hidden author" in Punjabi literary history-Bhaag Bhari, Waris Shah's forgotten muse.

While Bhaag Bhari is never directly referenced by Waris Shah in his rendition of Hir, her legend has continued to circulate in the folk corpus. The story goes that as a young man Waris Shah fell in love with a woman named Bhaag Bhari. However, Waris himself belonged to a wealthy Syed family, and the differences in caste and status precluded his union with Bhaag Bhari. It is popularly believed that Waris Shah was thus inspired to write the qissa of Hir. Little is known about Bhaag Bhari's life. In "Blue cloth dyed blue," Bhatti revives Bhaag Bhari as the moving force behind the coveted treasure of classical Punjabi poetry, Hir Waris Shah, by incorporating her persona into the poem's narrative structure.

Bhatti begins by invoking a well-worn convention of the Punjabi qissa, which often begins with a declaration of intent and sources by the poet. For example, Damoodar Das, a sixteenth century poet of Hir announces in his opening verses: "I write what I saw with my own eyes, I have no other craft..." Similarly, Waris opens his eighteenth century version of the Hir qissa with, "Friends came and requested me/ Let's make the story of Hir anew." Echoing this method, Bhatti (1979) commences her historiographical revision of Hir and Punjab's literary tradition with: "What will the military office tell you? The trees of stories are inscribed on my chest/ Shall I tell you if I am Noor Bhari or Bhaag Bhari?" (p. 30). While the classic tellings of Hir by these male poets emphasize the act of witnessing (Damodar) and renewal (Waris Shah) in response to historical circumstances, Bhatti's authorial claim expresses a historiographical urge rooted, quite literally, like trees in the chest of the female poet, in her gendered subjectivity. The challenge to the "military office" is also not to be missed, an allusion to the military regime and its project of cultural reconstruction that sought to stifle marginalized voices-women, workers, religious minorities-to impose a hegemonic Sunni identity that allied with the State's strategic alignment with Saudi Arabia, to the detriment of "Indic" and regional expressions of identity. By invoking a peripheral folk legend involving an ordinary woman, Bhatti simultaneously critiques the effacing of women from the public sphere, and the flattening out of regional histories to benefit an Islamist state ideology.

Having destabilized both the contemporary patriarchy of the military regime and the male claims to authenticity inscribed in the Hir qissa tradition, Bhatti directs the persona of Bhaag Bhari towards an interrogation of Waris Shah as author and creator:

Kon ai, tere waris kithai ne?

Mein tandoorai baethi ne virasata(n) sar chadia(n) ne(n) warisa! 
kehri virasat asi(n) te pakhi vas honai a(n)

par tu(n) kon ai(n) chora? Nivi(n) payi baitha ai(n), ilm da chatta peya marna ai(n)

[Who are you, where are your heirs (your "Waris")?

Oh Waris, I sat at the hearth and burned all things to be inherited

We have no possessions; we are nomads after all

But you, who are you, thief? Throwing the weight of your knowledge about?]

(Bhatti 1979:30)

While Pritam's poem de-centered Waris Shah by holding him to account, Bhatti's appropriation of Bhaag Bhari displaces him entirely. The verses imply that Waris Shah "stole" his Hir from Bhaag Bhari, a suggestion reinforced by Bhatti's play on his name - "Waris" is a given name, but it also means heir, owner, master and protector. By accusing him of being a "thief" wielding the weight of "knowledge," Bhatti calls into question the ossification of literary tradition into a male lineage of poets, drawing our attention to the effacing of women's creative potential in political, social and cultural developments over the centuries. To counter the Pakistani state's re-writing of history through a communal and patriarchal lens that would confine women to "chadar and char divari" (The veil and the four walls [of the home]), Bhatti presents a literary method rooted in the dialogic tension pioneered by Hir that brings to light an alternative history of Punjab and its poetic tradition. She re-interprets and ruptures key moments from the region's cultural history through a constellation of female characters from folk imagination, who converge around Bhaag Bhari and the poet to establish women as active subjects and reflexive authors of history.

Bhaag Bhari's indictment of Waris Shah paves the way to an acknowledgment of the revolutionary agency of Ladhee, who appears in the popular var or ballad, "The ballad of Dullah Bhatti." ${ }^{19}$ In the narrative, Ladhee, Dullah's mother, is painted as a spirited and assertive woman who sharply critiques Mughal power. She is pivotal in reminding Dullah Bhatti of his duty to rebel, and as his mother, symbolizes the birthing ground of regional resistance. Yet popular culture valorizes Dullah Bhatti as a masculine hero defined by his individual merit, with no reference to the context of popular resistance. Bhatti's poem implores us to "Tell Ladhee to bring a daughter into the world now, not a son" (Bhatti 1979:30), a nod to the rising women's movement, and a poetic reworking of vernacular history that focuses our gaze firmly on the gendered margins that are excluded in the making of folk tradition. This move from a male-centric tradition towards a feminist poetic practice is further emphasized by locating the origins of Hir Waris Shah in the open, creative expanses of the "vast hinterlands, away from the closed confines of the "courtyard" of the patriarchal father figure. Following Pritam, Bhatti addresses Waris Shah directly, asking "Are you scared of Bhaag Bhari?/Where did you get your Hir, from the vast hinterlands, or from Chuchak's courtyard?/Whose chest was it that birthed Hir, o Ranjha?" (Bhatti 1979:32). The chest that birthed Hir connects with the chest bearing "trees of stories"-the chest of Bhaag Bhari that has nourished the roots of history and literary tradition, embodying the lived experience of the silenced, female subject. Bhatti's "Blue cloth dyed blue" goes on to question the distinction between Bhaag Bhari and Hir Sial, asking provocatively: “Am I Bhaag Bhari or Hir Sial?" (Bhatti 1979:34). This move allows Bhatti to demolish the distinction between text and author, between woman as object and woman as subject. Taking her cue from Hir's exegetical challenge to the Qazi's ideological instruments, Bhatti reworks poetic convention to connect contemporary feminist concerns with regional genealogies of critique. 


\section{Conclusion: theorizing a feminist "Punjabiyat"}

25 requiring a framing of the self as a distinct subject exercising a certain agency, yet her study of Peero's poetry demonstrates the difficulty of separating colonial and precolonial literary sensibilities in South Asia. Peero was a Muslim woman who "came to live sometime in the 1830s in the Gulabdasi dera of Guru Gulab Das (1809-1873) in Chathianwala near Lahore" (Malhotra 2009:542). The Gulabdasis were a marginal "Sikh" sect drawing on a "mixed inheritance from Indic and Islamicate sources" (p.543). Malhotra argues that Peero drew on an "earlier episteme" (p. 544) and its cultural resources to tell her tale, appropriating "an Indic and a regional alternative tradition to stitch legitimacy to her own rebellion" (p. 588). As our analysis of Bhatti's "Blue cloth dyed blue" shows, a woman living in postcolonial Pakistan in the 1970s, well after the establishment and subsequent dismantling of the British colonial state, was similarly able to insert her concerns into the narrative of Hir to return to and revise the generative roots of the Punjabi poetic tradition.

his adoption of regional tradition, also seen in Pritam's "Today I call on Waris Shah" has been grossly misread in studies of postcolonial Punjab and literary cultures in South Asia, an endeavor complicated by the fact that we are confronted with three Punjabs today: Pakistani, Indian and diasporic. Each has its unique experience of identity, politics and cultural development, yet threads of commonality continue to unite them, particularly in the imaginative arenas of creative expression and cultural production. Studies of postcolonial Punjab have gone a long way towards highlighting the separatist current active from the late 1970s to the early 1990s in Sikh-dominated East Punjab on the one hand, and emphasizing the place of Muslim-dominated West Punjab as the dominant, "ethnic hegemon" (Ayres 2009:28) on the other. However, an emphasis on the state as the sole site for cultural expression and identity politics has overshadowed the enduring influence of shared pre-colonial cultural formations on the contemporary context. For example, studies of the Punjabi literary movement in Pakistan of the 1970s view the Punjabi literary movement that Nasreen Bhatti belonged to as a literary sphere that cultivated an "ethno-nationalist" consciousness to salvage the "lost valor" of a masculine "heroic Punjab" (Ayres 2009:75). ${ }^{20}$ This misreading results from a privileging of the interpretive lens of nationalism to explain language politics and regional writing, and confuses the critical deployment of poetic tradition informed by "Marxist-inspired literary methodologies" (Butt and Kalra 2013), failing to appreciate the jagged edges introduced into the idea of "Punjabiyat" by writers like Bhatti and Amrita Pritam.

As our readings show, these poets' relationship with Punjab and Punjabi cannot be seen as a simplistic assertion of ethnic pride or linguistic identity. Their engagement with Punjabi history and culture was instead a "complicated and resistant habitation" (Gopal 2005:6): Punjabi authors like Bhatti and Pritam remained "obstinately insistent on their locatedness" (p. 6) within the historical-cultural terrain of Punjab, even as they offered "persistent and excoriating critiques" (p. 6) of its regressive tendencies. Attention to such sites of critique allows us to "interrogate and rethink influential templates for the postcolonial intellectual" (p. 7), enriching our understanding of writing in the regional vernaculars beyond seeing them as an undifferentiated mass defined by amorphous ideas of ethnicity, local identity and provincial politics. As Bhatti and Pritam show through

South Asia Multidisciplinary Academic Journal , Free-Standing Articles 
their contemporary engagement with the Hir tradition, the precolonial past and the postcolonial present are often erroneously bifurcated in a way that today prevents emancipatory projects from connecting with the voices of literary resistance in our history.

\section{BIBLIOGRAPHY}

Ahmad, Aijaz. 1992. In Theory: Nations, Classes, Literatures. London; New York: Verso.

Asdar Ali, Kamran. 2011. “Communists in a Muslim Land: Cultural Debates in Pakistan's Early Years.” Modern Asian Studies 45:501-34.

Ayres, Alyssa. 2009. Speaking Like a State: Language and Nationalism in Pakistan. Cambridge: Cambridge University Press.

Aziz, Abdul. ed. 1960. Hir Sayyid Waris Shah. Lahore: Punjabi Adabi Academy.

Ahmad, Aziz. 1963. "Epic and Counter-Epic in Medieval India." Journal of the American Oriental Society $83(4): 470$.

Bearman, P. J., et al. 2012. Encyclopaedia of Islam: Glossary and Index of Terms. $2^{\text {nd }}$ ed. Retrieved February 20, 2019 (https://referenceworks.brillonline.com/entries/encyclopaedia-of-islam-2Glossary-and-Index-of-Terms/kafi-SIM_gi_01965).

Bhatti, Nasreen Anjum. 1979. Nil karaiyan nilkan. Lahore: Suchet Kitab Ghar.

Butt, Waqas and Virinder Kalra. 2013. “'In One Hand a Pen in the Other a Gun': Punjabi Language Radicalism in Punjab, Pakistan." South Asian History and Culture 4(4):538-53.

Cohn, Bernard. 1996. Colonialism and its Forms of Knowledge: The British in India. Princeton: Princeton University Press.

Deol, Jeevan. 1997. “To Hell with War': Literature of Political Resistance in Early NineteenthCentury Punjab.” South Asia Research 17(2):178-209.

Deol, Jeevan. 2002. "Sex, Social Critique and the Female Figure in Premodern Punjabi Poetry: Vāris Shāh's 'Hīr." Modern Asian Studies 36(1):141-71.

Gopal, Priyamvada. 2005. Literary Radicalism in India: Gender, Nation and the Transition to Independence. Hoboken: Taylor and Francis.

Jha, Jama and Amrita Pritam. 1982. "An Interview with Amrita Pritam." Indian Literature 25 (5):183-95.

Kalra, Virinder. 2014. "Punjabiyat and the Music of Nusrat Fateh Ali Khan." South Asian Diaspora 6 (2):179-92.

Kaviraj, Sudipta. 2005. "Writing, Speak, Being: Language and the Historical Formation of Identities in India." Pp. 312-50 in Language and Politics in India, edited by A. Sarangi. New Delhi, India: Oxford University Press.

Lazarus, Neil. 1999. Nationalism and Cultural Practice in the Postcolonial World. Cambridge: Cambridge University Press. 
Malhotra, Anshu. 2009. “Telling Her Tale? Unravelling a Life in Conflict in Peero’s Ik Sau Sațh Kāfian: (One Hundred and Sixty Kafis).” The Indian Economic \& Social History Review 46(4):541-78.

Malhotra, Anshu and Farina Mir. 2012. Punjab Reconsidered: History, Culture, and Practice. $1^{\text {st }}$ ed. New Delhi, India: Oxford University Press.

Matringe, Denis. 1995. "The Panjab and its Popular Culture in the Modern Panjabi Poetry of the 1920s and Early 1930s." South Asia Research 15(2):189-220.

Menon, Ritu and Bhasin, Kamla. 1993. "Recovery, Rupture, Resistance: Indian State and Abduction of Women during Partition." Economic and Political Weekly 28(17):WS2-WS11.

Mir, Farina. 2005. "Imperial Policy, Provincial Practices: Colonial Language Policy in Nineteenth Century India.” Indian Economic Social History Review 43(395):395-427.

Mir, Farina. 2010. The Social Space of Language: Vernacular Culture in British Colonial Punjab. Berkeley: University of California Press.

Najabat. 2010. Najabat di vaar. Lahore: Suchet Kitab Ghar.

Petievich, Carla, trans. 2008. When Men Speak as Women: Vocal Masquerade in Indo-Muslim Poetry. New Delhi: Oxford University Press India.

Pritam. N.d. Navin rutt. Lahore: Suchet Kitab Ghar.

Pritam. 1979. “To Waris Shah." Pp. 11 in Alone in the multitude, edited and translated by S. Kohli. New Delhi: Indian Literary Review.

Pritam. 1994. The Revenue Stamp: An Autobiography. New Delhi: Times New Group.

Pritam, Amrita. 2006. “I Call on Varis Shah!” Translated by G. Schreffler. Journal of Punjab Studies $13: 1-2$.

Qadri, Asma. 2011. “Vaar” Pp. 69-106 in Punjabi classiki shairi da sinf vaerva, pehla hissa. Lahore: Punjab University Press, 2011.

Rahman, Tariq. 1996. Language and Politics in Pakistan. Karachi: Oxford University Press.

Ramakrishna, Lajwanti. 1977. Panjabi Sufi Poets: AD 1460-1900. Karachi: Indus Publications.

Ramanujan, Attipat Kris. 1989. "Where Mirrors Are Windows: Toward an Anthology of Reflections." History of Religions 28(3):187-216.

Renard, John. 2005. Historical Dictionary of Sufism. Lanham, MD: Scarecrow Press.

Rouse, Shahnaz. 1986. “Women's Movement in Pakistan: State, Class, Gender.” South Asia Bulletin 6(1):30-37.

Sabar, Muhammad Sharif, ed. 1986. Hir Waris Shah. Lahore: Waris Shah Memorial Trust.

Schimmel, Annemarie. 1975. Mystical Dimensions of Islam. Chapel Hill: University of North Carolina Press.

Shackle, Christopher. 1970. "Punjabi in Lahore." Modern Asian Studies 4:239-67.

Shackle, Christopher. 2012. "Punjabi Sufi Poetry from Farid to Farid." Pp. 3-34 in Punjab Reconsidered: History, Culture and Practice, edited by A. Malhotra and F. Mir. New Delhi: Oxford University Press.

Shah, Bulleh. 2012. Chonviaan Kafian. Lahore: Suchet Kitab Ghar.

Shah, Waris. 2006. Hir Waris Shah. Lahore: Millat Publications.

Sobti, Krishna. 2016. Zindaginama. New Delhi: Harper Collins India. 
Syed, Najm Hosain. 1968. Recurrent Patterns in Punjabi Poetry. Lahore: Punjab Adbi Markaz.

\section{NOTES}

1. I have used the Romanization scheme created by the US Library of Congress and the American Library Association for Punjabi in the Gurmukhi script, however, I have left out the diacritics, and nasalization has been indicated using “(n)."

2. Mir (2005) informs us that the Punjabi qissa, as a genre, has its roots in the Arabic and Persian storytelling traditions. It has particular affinity with the Persian romance qissa, and the masnavi poetic form, which were transmitted to South Asia during the medieval period. South Asian poets began composing qisse in Persian, the court language of the time, but slowly, the genre was adopted by regional vernaculars (Mir 2005:7). The Punjabi qissa follows the typical pada rhyme scheme, but uses indigenous rather than Persian metres, also incorporating local romances.

3. This translation is adapted from two translations: Amrita Pritam. 2006. "I Call on Varis Shah!" Translated by. G. Schreffler; Amrita Pritam. 1979. "To Waris Shah." Edited and translated by S. Kohli. All other translations are mine unless otherwise stated.

4. For more detail on the Hir narrative in history, in particular its development during the colonial period, see Mir (2010).

5. Jogi is derived from the Sanskrit word, "jog" or "yog," which refers to joining, or yoking together. The jogi appears in this narrative, and Punjabi culture generally, as a wanderer and ascetic. In Hir Waris Shah, Ranjha joins the sect of the famed jogi Balnath, becoming his disciple.

6. As with any text that has circulated orally, editions have been compiled by drawing on both orature and historical manuscripts. I have referred to the versions produced by Sheikh Abdul Aziz (1960) and Sharif Sabar (1986) for my translations.

7. In his Historical Dictionary of Sufism, Renard (2005) translates "qutb" as "pole." The term is used to refer to individual Sufi leaders sometimes identified as the cosmic axis, pivot, or pole of an age. "Some consider the pole of each age to be the manifestation of the spirit of the Prophet for that time" (p. 185).

8. The word used here by Waris Shah is "daira," which translates as "circle," referring here to the practice of public debate and intellectual deliberation, where all participate as equals. More specifically, "sitting in dairas (circles)" points us to the "panchayat"-the regular, if not daily, congregation amongst the men of the village to discuss politics and other affairs pertaining to the community.

9. The Punjabi kafi is a popular genre of Punjabi literature. It comprises "a lyric consisting of rhymed couplets or short stanzas having a refrain repeated after each verse..." (Bearman et al. 2012) Prominent exponents of the Punjabi kafi include Shah Hussain (1538-1599) and Bulleh Shah (1680-1757)

10. See for instance, Ramakrishna (1977), Schimmel (1975) and Shackle (2012). Petievich (2008), despite her gendered critique of Punjabi poetic tradition, also views the corpus as an instrument in the hands of the Sufis, yielded to pare down a theological message.

11. For instance, the publication in 1932 of Angarey, a collection of short stories that focused on the North Indian Muslim community and presented a critical self-reflection on issues surrounding women's bodies, sexuality, and masculinity, became a generative moment for progressive writing in the subcontinent. The collection provoked a great deal of controversy, and was eventually banned by the colonial state. For more, see Gopal (2005).

12. A similar evocation of Punjab's cultural and physical landscape can also be found in Krishna Sobti's novel, Zindaginama, first published in Hindi in 1979, with an English translation in 2016. Sobti deploys a similar technique, working sources from the oral tradition into her narrative form. 
13. The trinjann was the communal space where women from the village would gather and work. In the Punjabi poetic tradition, the trinjann has developed into a salient symbol, representing the spirit of collectivity and equality, and often a stage of innocence, where girls play before they are married and have to leave their own villages.

14. In some editions, the stanzas of Hir Waris Shah appear with Persian headings that were found in some of the manuscripts from the nineteenth century. The Persian title for this particular stanza is "Faryaad Ranjha" which translates as "The cry of Ranjha," thereby attributing these lines to Ranjha as he watches Hir being paraded out of town in a wedding procession. However, some scholars such as Sharif Sabar and Najm Hosein Syed concur that the Persian sub-headings are a later addition to Waris Shah's original text.

15. The title, "Nil karaiyan Nilakan" is not an easy one to translate. "Nilak" refers to a dark blue precious stone, as well as a piece of blue cloth worn wrapped around the waist to cover the lower body (a lungi). Nilak is also a richly embroidered cloth, with yellow threadwork set against a red or black background, and, a valuable item of clothing worn on festive occasions. In his article in The Friday Times, Waqas Khwaja points us towards another possibility, linking Bhatti's title to " Nilkar," a medicinal herb with blue flowers known as "hound's tongue." I have chosen to work with Blue cloth dyed blue to try to capture as many of its meanings as possible.

16. Bhutto's Pakistan People's Party (PPP) eventually turned out to be yet another "stained dawn" for progressives, with his regime undertaking one of the most brutal repressions of the workers' movement in Pakistan's history.

17. Jeevan Deol (1997) defines the vaar as "a narrative poem in stanzas often sung to the accompaniment of interspersed oral narration, which usually deals with battles and conflicts" (p. 185), identifying its corpus as a "literature of resistance" (p. 179) that emerged as a "counterepic" in relation to the Persian "epic of conquest." (Ahmad 1963:470) Some popular vaars include Dullah Bhatti di vaar, Chattheyan di vaar, and Najabat di vaar. For more, see Asma Qadri's (2011) chapter on the genre in Punjabi classiki shairi da sinf vaerva, pehla hissa.

18. The female character of Kaal appears as a mythological character, thirsting for blood and driving the hero to battle. She symbolizes a force of creative destruction. See for instance, Najabat (2010). The word is also used to refer to time, and to death.

19. According to the popular ballad, Dullah Bhatti followed in the footsteps of his father and grandfather in resisting Mughal hegemony in Pindi Bhattian, Punjab, attacking Mughal trade caravans and refusing to pay the hefty land tax imposed by the state's agrarian system in sixteenth century North India. Dullah Bhatti was finally captured by Akbar and executed publicly in Lahore. He has been celebrated as a regional hero and rebel in folklore, and in the progressive circles of contemporary Punjab.

20. Also see, for instance, Shackle (1970), and Rahman (1996). While Rahman identifies "sentimental attachment" as the primary motivation of Punjabi language activists, Shackle locates the movement within the "shadowy political movements of the period, aimed at securing greater political autonomy" (p. 266).

\section{ABSTRACTS}

This paper explores the feminist poetics of postcolonial Punjabi poetry, focusing specifically on Amrita Pritam and Nasreen Anjum Bhatti. Through a close reading of their poems, "Ajj aakhan 
Waris Shah nu" ["Today I Call on Waris Shah"] and "Nil karaiyan nilkan" ["Blue Cloth Dyed Blue"], I argue that these progressive poets deployed the contestatory genre of Hir to critique the multiple patriarchies of nation, region and community. Their radical re-working of Hir's voice attempts to de-center male authorial privilege in the Punjabi literary formation, constituting the regional vernacular as a potent site for engaging with tradition under modernity. Together, their poems offer a historiographical and literary reconstruction of cultural identity to locate women as active subjects and narrators of history.

\section{INDEX}

Keywords: Pritam (Amrita), Bhatti (Nasreen Anjum), Punjabi literature, postcolonial literature, Hir Waris Shah, Shah (Waris), Punjabiyat, vernacular writing

\section{AUTHOR}

SARA KAZMI

University of Cambridge 